Old Dominion University ODU Digital Commons

Fall 2012

\title{
Changing and/or Funding OPEB Promises: A Typology of Local Government Responses to GASB 45 and the Realization of OPEB Liabilities
}

Juita-Elena Yusuf

Old Dominion University, jyusuf@odu.edu

Thomas Musumeci

Old Dominion University

Follow this and additional works at: https://digitalcommons.odu.edu/publicservice_pubs

Part of the Accounting Commons, Economic Policy Commons, Finance and Financial Management Commons, and the Public Administration Commons

\section{Repository Citation}

Yusuf, Juita-Elena and Musumeci, Thomas, "Changing and/or Funding OPEB Promises: A Typology of Local Government Responses to GASB 45 and the Realization of OPEB Liabilities" (2012). School of Public Service Faculty Publications. 16.

https://digitalcommons.odu.edu/publicservice_pubs/16

\section{Original Publication Citation}

Yusuf, J.E., \& Musumeci, T. (2012). Changing and/or funding OPEB promises: A typology of local government responses to GASB 45 and the realization of OPEB liabilities. Journal of Public Budgeting, Accounting \& Financial Management, 24(3), 369-396.

This Article is brought to you for free and open access by the School of Public Service at ODU Digital Commons. It has been accepted for inclusion in School of Public Service Faculty Publications by an authorized administrator of ODU Digital Commons. For more information, please contact digitalcommons@odu.edu. 


\title{
CHANGING AND/OR FUNDING OPEB PROMISES: A TYPOLOGY OF LOCAL GOVERNMENT RESPONSES TO GASB 45 AND THE REALIZATION OF OPEB LIABILITIES
}

\author{
Juita Elena (Wie) Yusuf and Thomas Musumeci*
}

\begin{abstract}
GASB Statement No. 45 addresses how governmental units account for employees' other post-employment benefits (OPEB), requiring government employers to replace OPEB reporting on a pay-as-you-go basis with an accounting of the cost of current and future benefits. This requirement and the resulting OPEB liability may prompt government employers to reconsider key questions regarding their OPEB provision. The size of the OPEB liability depends on both the benefit promises made to employees and the assets to fund these promises. We propose a typology that defines four approaches for governments to respond to GASB 45 and their OPEB liabilities. These approaches represent different combinations of strategies involving OPEB promises and assets. We illustrate these strategies and responses using selected counties and nine mid-Atlantic cities.
\end{abstract}

\section{INTRODUCTION}

In June 2004, the Governmental Accounting Standards Board (GASB) issued Statement No. 45 (GASB 45) Accounting and Financial Reporting by Employers for Postemployment Benefits Other than Pensions to require clear and transparent reporting of the current

* Juita-Elena (Wie) Yusuf, Ph.D., and Thomas Musumeci are an Assistant Professor, and a doctoral candidate, respectively, Department of Urban Studies and Public Administration, Old Dominion University. Dr. Yusuf's research interests are in public budgeting and financial management, with a particular interest in transportation finance, and transparency, accountability and public participation. Musumeci's research interests are in local government budgeting and finance. He is the Deputy Treasurer for the City of Virginia Beach, Virginia.

Copyright (c) 2012 by PrAcademics Press 
value of other post-employment benefits (OPEB) promises in state and local government financial statements. These OPEB are defined as non-pension benefits provided after an individual leaves. employment. They primarily include retiree healthcare, and often dental, vision, and prescription drug plans, but possibly also life insurance, disability, long-term care, and legal services if they are provided separately from a defined benefit pension plan. Given that health benefits are by far both the predominant and the most costly OPEB for government employers, our research focuses primarily on retiree health benefits.

OPEB have traditionally been reported and paid for on a pay-asyou-go (PAYGO) basis. GASB 45, however, established new accounting standards for state and local governments as employers, requiring them to measure, recognize, and disclose the cost of their OPEB in their financial reports. Compliance with GASB 45 reporting guidelines provides employers with an understanding of their OPEB actuarial liability exposure.

While intended solely as an accounting standard, GASB 45 may significantly affect the funding, sponsorship, and design of OPEB. This paper focuses on local government responses to GASB 45 and the information it discloses regarding OPEB liability, and summarizes decisions made by selected county and city governments in response to the realization of the magnitude of their OPEB liabilities following compliance with GASB 45. This focus on local governments is critical, as of the over 89,000 local governments in the US, approximately 77 percent provide OPEB to their retirees (Bell, 2006).

We ask the following research question: How have local governments in the U.S. responded to GASB 45 and the resulting information about unfunded OPEB liabilities? Answering this research question is timely given the recent implementation of GASB 45. It is also relevant given the potential size of OPEB liabilities. Coupled with the current fiscal crisis, OPEB liabilities may prompt local governments to re-think the fundamental question of whether to continue to provide OPEB. Our research examines the decisions made by local governments regarding the continued sponsorship of retiree healthcare benefits, prefunding of such benefits, and subsequent benefit plan redesign and other cost cutting strategies to accommodate continued sponsorship in the face of significant liabilities and annual funding requirements. We illustrate, using a 
four-cell typology, how local governments have responded to the informational content of GASB 45. We frame these responses in terms of changing OPEB promises and/or building assets to fulfill these promises.

We begin with a brief overview of GASB 45 and discuss the potential impacts of GASB 45 on government employers. Against this backdrop we introduce four possible categories of responses to GASB 45. These responses involve different combinations of prefunding OPEB and maintaining benefit levels. We illustrate these responses using a study of counties by the National Center for the Study of Counties (NCSC) and examples of nine mid-Atlantic cities. We highlight how some local governments' responses to GASB 45 have resulted in reduced OPEB.

\section{BACKGROUND ON GASB 45}

GASB 45 is the governmental equivalent to Financial Accounting Standards Board Statement 106 (FAS 106) and International Accounting Standards Board Statement 19 (IASB 19). GASB 45 was partly motivated by economic and demographic factors, such as the impending baby boomers' retirement and escalating healthcare costs that threaten to significantly increase the costs to government employers for retiree benefits (Marlowe, 2008). The traditional PAYGO approach to OPEB can result in inadequately prefunded benefits that may in turn contribute to mounting deferred liabilities and potentially adverse effects on the fiscal health of government entities. The importance of GASB 45 was spurred by most subnational governments' not reporting or disclosing in their financial documents information pertaining to the amount of their OPEB obligations, making it impossible for the public to determine the true cost for government of providing these benefits.

OPEB costs have traditionally been accounted for and funded on a PAYGO basis, with current year benefits and administrative costs paid out of current revenue. In establishing Statement No. 45, GASB (2004) noted that the PAYGO approach and its related reporting failed to (1) recognize the cost of benefits when the exchange of benefits and service takes place, (2) provide information about the actuarial accrued liabilities for promised benefits and the extent to which these benefits have been funded, and (3) provide information needed to assess potential demands on future cash flows. In 
essence, the problem with the PAYGO approach is that it allows governments to ignore future expenses associated with benefits promised to retirees, and to underreport substantial accumulated liabilities that have been incurred and will be incurred in the future. GASB 45 was driven by two inter-related issues (Governmental Accounting Standards Board, n.d.). First was the lack of reporting and information about the nature and size of long-term OPEB obligations and commitments, and second was the incomplete information with which to assess the cost of government and to analyze the financial position and long-run financial health of government. GASB 45 addressed concerns that the PAYGO approach was "not transparent and obscured the magnitude of government employers' financial obligation ... [and] the funded status of postretirement obligations was not disclosed and was not recognized on the financial statements" (Bell, 2006, p. 29).

OPEB are a form of deferred compensation and should be recognized and recorded as the benefits are earned, rather than recognized in the future when the benefits are paid (Mead, 2008). GASB 45 establishes an amortization period so government employers can account for the cost of OPEB over the active service life of employees. From an informational perspective, GASB 45 dictates that employers offering defined benefit OPEB plans must measure and disclose their long-term OPEB costs and the extent to which the employers have contributed to meet those costs. In summary, GASB 45 requires that government employers produce statements for their OPEB using generally accepted accounting principles that present the estimated actuarial accrued liabilities and the annual required contributions necessary to cover the liabilities. In much the same way as GASB Statement No. 43 changed how subnational governments report the liabilities associated with their pension plans, GASB 45 changes how state and local governments report the liabilities associated with their OPEB plans.

\section{Informational Components of GASB 45}

According to Wisniewski, "the new OPEB standards provide information about whether and to what extent promised benefits have been funded, as well as information about the potential impact by such benefits on the employer's future cash flow" (2005, p. 106). GASB 45 can "[p]rovide information useful in assessing potential 
demands on the employer's future cash flows" (http://www.gasb.org/st/summary/gstsm45.html). It requires the measurement, recognition, and reporting of annual OPEB costs on an accrual accounting basis, which allows for the systematic and rational allocation of the present value of the OPEB over the working life of employees.

The determination of the OPEB costs and liabilities begins with calculating the annual required contribution (ARC). There are two components to the ARC. The first is the employer's normal costs or the present value of providing one year of the OPEB to all qualifying retirees. The second component of the ARC is the amortized costs of the OPEB liability. These amortized costs represent "[t]he portion of the actuarial present value allocated to prior years of employment and thus not provided for by normal costs in the current or future years" (Mead 2008, p. 290). The actuarial accrued liability (AAL) is the total amount of the OPEB earned by employees up to the date that GASB 45 is implemented and is amortized over thirty years. It represents "the amount that the organization should have been contributing in the periods prior to the implementation of the OPEB standard" (Voorhees, 2005, p. 64).

Compliance with GASB 45 also involves determining the unfunded actuarial accrued liability (UAAL) which is the amount by which the actuarial value of the OPEB plan assets exceeds the AAL. For governments using PAYGO, the UAAL will be equal to the AAL as the OPEB plan will have no assets. The UAAL can also be defined as the cumulative annual ARC short- falls.

The content of the information resulting from GASB 45 is daunting. Given that many governments have traditionally relied on the PAYGO approach to finance their OPEB, GASB 45 was expected to result in reporting of significant, eye-opening, unfunded liabilities. Mckethan et al. (2006) reported that the AAL could amount to as much as \$1 trillion nationwide. Keating and Berman (2007) cited estimates of OPEB liabilities in the $\$ 1$ trillion (McTague, 2006) to $\$ 1.5$ trillion (Zion \& Varshney, 2007) range. Estimates by the Government Accountability Office (2007) showed an aggregate state and local government unfunded liability of between $\$ 500$ billion and $\$ 1.6$ trillion. Research by Credit Suisse estimated that the 25 largest cities had unfunded OPEB liabilities of over $\$ 90$ billion (Zion \& Varshney, 2007). OPEB liabilities for the City of Los Angeles alone 
were projected to be $\$ 93$ billion, equivalent to $\$ 8,000$ per resident (Marlowe, 2008). More recently, Coggburn and Kearney (2010) provided data on OPEB liabilities of individual states, which ranged from effectively $\$ 0$ to $\$ 68$ billion. Fourteen states had OPEB liabilities in excess of $\$ 10$ billion.

Clearly these liabilities, and the resulting funding requirements, can have serious consequences for governmental balance sheets, just as the implication of FAS 106 discussed next had serious consequences for the balance sheets of many private companies.

\section{POSSIBLE RESPONSES TO GASB 45 AND THE SUBSEQUENST REALIZATION OF OPEB LIABILITIES}

GASB 45 brings public sector accounting practices in closer alignment with the private sector pension accounting rules instituted in response to several highly publicized private sector pension fund collapses. Hurley et al. (2006) viewed GASB 45 as the public sector equivalent of FAS 106, to which many attributed a steep decline in private sector retiree healthcare benefits (Patterson, 2001).

\section{Learning from the FAS 106 Experience}

Pearson and Jerris (1995) argued that including liability reporting for OPEB reduced healthcare and other benefits received by private sector employees and retirees. FAS 106 became effective December 15,1992 , and statistics show that the private sector has since seen decreasing retiree health benefits. In 1997, 22 percent of private sector employers provided retiree health benefits, but by 2002 , only 13 percent provided such benefits (Kilgour, 2009). Other studies documented this positive relationship between reduction in benefits and the implementation of FAS 106 (Mittelstaedt, Nichols, \& Regier, 1995; Binnis \& Riffe, 2000).

The private sector experience with FAS 106 suggests that despite its intended role as simply an accounting and reporting standard that requires government employers to recognize OPEB costs, GASB 45 could result in these government employers reducing or even eliminating their OPEB. Kilgour suggested that "the major short run impact of GASB 45 will be to pressure employers to reduce costs by reducing retiree health and other benefits by curtailing access and benefit levels and shifting more of their cost to retirees" (2009, p. 
32). Therefore, while GASB 45 is an accounting standard and does not mandate how a governmental entity conducts its operations, "[c]onsideration of the information produced by the application of the standard may encourage ... governments to think about reducing such benefit programs (and their associated liabilities) in the future" (Wiesnewski, 2005, p. 115).

Coggburn and Kearney (2010) argued that while GASB 45 has made OPEB costs more transparent, the resulting unfunded liabilities have prompted a concern "over the sustainability of many government benefit plans" (p. 106). Many of the questions being addressed by government employers today are equivalent to those resulting from FAS 106 . These companies had to consider the sustainability of continuing to provide retiree healthcare benefits in their existing forms, and subsequently what types of plan design changes or cost control measures could be instituted and how they would be instituted. Companies also had to consider whether to prefund their retiree healthcare plans and how much to prefund. Both sets of questions are examined in this study. The former focuses on whether to continue providing OPEB and if so, what types of changes might be made to the OPEB plan. These questions are important because they affect the assumptions underpinning the OPEB actuarial valuation, which may result in "nontrivial differences" in the OPEB liabilities (Marlowe, 2008, p. 216). The latter question of prefunding deals with building the assets base for addressing future liabilities. The responses to these questions are important because they determine the extent of OPEB liability underfunding.

\section{Changing OPEB Promises: Continuing OPEB Provision and At What Levels?}

As private sector employers dealt with FAS 106, some considered discontinuing their retiree healthcare benefits or ending participation for future retirees or new hires. Several companies implemented changes to their OPEB plans, affecting benefit levels, eligibility, and the cost sharing relationship. Some private employers began to tie their retiree healthcare benefits to greater lengths of service with the company or introduced graded vesting and accruing retiree healthcare benefits over the employees' working careers. Other elements of plan design that came under scrutiny were the provision of full benefits to spouses at no cost, the provision of full benefits at younger retirement ages, and the level of benefits provided (Feldman 
\& Haynes, 2007). To ameliorate the financial impact of FAS 106 , some companies capped the amount the employer would contribute toward retiree healthcare benefits. Also to reduce their financial burden, employers shifted away from a defined benefit (DB) plan to a defined contribution (DC) plan. These approaches had the key advantage of reducing both the employer's liabilities and expenses for such benefits. Similar actions are expected to be taken by government employers as they deal with GASB 45.

In situations where government employers may be considering plan redesign, the focus will typically be on preserving as much as possible the expectations of present retirees, while allowing the greatest changes to affect new future hires. While there is usually much more flexibility to change retiree benefits for new employees, public sector unions and the relevant labor laws may influence the government employer's ability to change its retiree benefits (Moran, 2010). The power of government employees and their unions in particular has been shown to be an important factor influencing governments' decisions regarding retiree benefits (McKethan et al., 2006). In some jurisdictions, unions are strong and can prevent unilateral action by the government employer. Other jurisdictions may be similarly constrained if their OPEB have constitutional, statutory, or judicial status that precludes or limits what governments can do, especially for retirees and incumbent employees.

\section{Building the Assets Base: Should the Government Employer Prefund?}

A key component of GASB 45 is the option of prefunding OPEB. Doing so provides a vehicle for building an asset base to offset the actuarial accrued liabilities and pay for the benefits as they come due in the future. The growth of the assets, theoretically, provides greater benefit security for retirees (Young, 2005) as more revenues into the plan, over time, come from investment income. The new OPEB reporting standards do not require that the OPEB be prefunded or that funds be held in trust. However, prefunding and setting up an irrevocable trust are recommended best practices for local. governments implementing GASB 45 (Coe \& Rivenbank, 2010).

Government employers can choose to continue to address their OPEB on a PAYGO basis. But there are long-term consequences of doing so, in that the OPEB liability and net obligation for the employer will continue to grow unchecked. With the PAYGO approach "the 
expensing is only out of pocket so there is not assistance against the accruing liability" (Bell, 2006, p. 34). However, there are significant obstacles to OPEB prefunding. For most employers the ARC payment is a large multiple of the PAYGO amount. Depending on the size of the OPEB plan, advance funding under the GASB 45 rules may add fiscal stress to the governmental entity (Young, 2005). 1 Prefunding, because it usually involves higher short-term costs compared with PAYGO, may introduce additional financial obligations at an inopportune time. This may prompt a reconsideration of OPEB levels instead of prefunding existing levels of benefits (Wiesnewski, 2005).

\section{A Four-cell Typology of Government Responses to GASB 45}

GASB 45 provides government employers with an understanding of their OPEB actuarial liability, which may raise the important issue of how to manage that liability (Young, 2005). The UAAL depends both on the promises to employees and the assets designed to fund these promises. Governments can respond to GASB 45 by focusing on both sides of the equation, by (1) changing benefits (i.e., the OPEB promises made to employees) and/or (2) building the OPEB assets needed to provide the benefits.

Government responses to addressing the OPEB liabilities that result from compliance with GASB 45 can be organized into a fourcell typology. This typology categorizes government responses based on two dimensions (see Figure 1). The first dimension is the OPEB promise made to employees. Government employers can either maintain the same OPEB promise as before implementation of GASB 45 , or reduce or eliminate benefits. ${ }^{2}$ The second dimension pertains to the assets and funding of OPEB. Here, governments also have two options, either to continue funding OPEB on a PAYGO basis, or to prefund OPEB. The four cells of the typology include a combination of these two dimensions. First, governments could maintain the status quo and make no changes to their OPEB benefits or to their PAYGO approach to funding OPEB (cell 1). Alternatively, government employers could prefund their OPEB and continue to provide the same OPEB benefits (cell 2). The remaining two response options both involve reductions in benefits, whether funding via PAYGO (cell 3 ) or by prefunding (cell 4). As the next section illustrates, local governments' response to GASB 45 are spread across these different categories. 
FIGURE 1

Four-Cell Typology of Government Employers' Responses to GASB 45 and Unfunded OPEB Liabilities

\begin{tabular}{|c|c|c|}
\hline \multirow{4}{*}{$\begin{array}{l}\text { PAYGO } \\
\text { approach }\end{array}$} & \multicolumn{2}{|c|}{ OPEB Promises } \\
\hline & $\begin{array}{l}\text { Maintain same benefits } \\
\text { as pre-GASB } 45\end{array}$ & $\begin{array}{c}\text { Reduce or eliminate } \\
\text { benefits }\end{array}$ \\
\hline & $\begin{array}{c}\text { 1. MAINTAIN STATUS } \\
\text { QUO }\end{array}$ & $\begin{array}{l}\text { 3. PAYGO WITH LOWER } \\
\text { BENEFITS }\end{array}$ \\
\hline & $\begin{array}{l}\text { 2. PREFUND WITH SAME } \\
\text { BENEFITS }\end{array}$ & $\begin{array}{l}\text { 4. PREFUND WITH } \\
\text { LOWER BENEFITS }\end{array}$ \\
\hline
\end{tabular}

HOW HAVE COUNTY GOVERNMENTS RESPONDED TO GASB 45 AND THE REALIZATION OF THEIR OPEB LIABILITIES?

In 2007, the National Center for the Study of Counties (NCSC) examined how counties across the country were responding to GASB 45 through case studies of 15 counties (Sanford, 2007). The study's findings indicate a range of responses, as shown in Appendix 1. Only a few selected examples from the NCSC study will be highlighted here to illustrate variations in how the responding counties addressed GASB 45 and its associated OPEB liabilities.

Fairfax County, Virginia, had an unfunded OPEB liability of $\$ 143$ million and an ARC of $\$ 15.2$ million. The county did not make any changes to its retiree healthcare plan, but instead focused solely on funding the ARC and creating an OPEB trust. Montgomery County, Maryland, followed a similar approach. The FY 2008 unfunded liability was $\$ 2.6$ billion and the ARC was $\$ 240$ million. Partly because 70 . percent of its employees are unionized, the county committed to full funding of the ARC over a 5 year period.

Sonoma County, California, on the other hand, adopted a twopronged strategy: (1) provide personal, professional, and political recognition of healthcare costs and their importance, and (2) protect health retirement benefits over the long term by making them sustainable. This sustainability was defined as a benefit level where the county could provide services to citizens yet also offer a fair 
compensation package to employees who deliver those services (Sanford, 2007). As a result, the county reduced its retiree healthcare contribution to a more sustainable level.

Gwinnett County, Georgia, also made changes to its OPEB, but only changed the insurance funding mechanism and not access to healthcare (Sanford, 2007). County leaders, realizing that their OPEB liabilities were not sustainable, created an OPEB trust fund to set aside assets to cover the liabilities and changed from paying a percentage of the retiree healthcare premium to paying a defined monthly contribution. This strategy has allowed the county to essentially lock in its OPEB liabilities at-more manageable levels.

Finally, Chester County, Pennsylvania, had an unfunded OPEB liability of about $\$ 4.4$ million, which prompted significant changes to its OPEB. To limit both exposure to such liabilities and the impact on taxpayers, the county eliminated the healthcare benefit for employees retiring after June 30, 2006.

\section{HOW HAVE CITY GOVERNMENTS RESPONDED? EXAMPLES FROM NINE MID- ATLANTIC CITIES}

To provide a more comprehensive examination of how local governments have responded to GASB, we supplemented the finding of the NCSC study with examples of how cities have responded to the information concerning their liabilities. By combining these examples of nine Mid-Atlantic cities in Virginia, Maryland, and North Carolina with the fifteen case studies of counties, we are able to better represent the different types of local governments in the U.S.

Three cities were selected from each of the three states: Baltimore, Gaithersburg, and Rockville in Maryland; Charlotte, Fayetteville, and Winston-Salem in North Carolina; and Alexandria, Richmond, and Virginia Beach in Virginia. These cities were selected to provide variety in terms of number of retirees, budget size, OPEB unfunded liability, and ARC. In addition we selected cities from both right-to-strike (Maryland) and right-to-work (Virginia and North Carolina) states. Table 1 summarizes the characteristics of the nine cities including government net assets, population, per capita income, UAAL and UAAL per capita. Appendix 2 provides a summary of the cities' responses to GASB 45. As can be seen from Table 1 and Appendix 2, the cities selected for case study vary widely not only 
in terms of government size and affluence, but also with regard to OPEB-related characteristics such as the AAL, UAAL and UAAL per capita, ARC, and number of government retirees. The examples from the nine selected cities are discussed next.

TABLE 1

OPEB Characteristics of Selected Cities (2008)

\begin{tabular}{|l|r|r|r|r|r|}
\hline City & $\begin{array}{c}\text { Total Govt } \\
\text { Net Assets } \\
\text { (in } \\
\text { billions) }\end{array}$ & \multicolumn{1}{|c|}{$\begin{array}{l}\text { Popula- } \\
\text { tion }\end{array}$} & $\begin{array}{c}\text { Per Capita } \\
\text { Income }\end{array}$ & $\begin{array}{c}\text { UAAL } \\
\text { (million) }\end{array}$ & \multicolumn{1}{|c|}{$\begin{array}{c}\text { UAAL Per } \\
\text { Capita }\end{array}$} \\
\hline Richmond, VA & $\$ 2.489$ & 200,123 & $\$ 39,860$ & $\$ 76.0$ & $\$ 379.77$ \\
\hline Alexandria, VA & $\$ 0.373$ & 141,000 & $\$ 65,141$ & $\$ 150.5$ & $\$ 1,067.38$ \\
\hline Virginia Beach, VA & $\$ 3.093$ & 434,072 & $\$ 43,578$ & $\$ 127.7$ & $\$ 292.74$ \\
\hline Baltimore, MD & $\$ 4.834$ & 637,455 & $\$ 32,445$ & $\$ 2,150.0$ & $\$ 3,161.01$ \\
\hline Gaithersburg, MD & $\$ 0.165$ & 59,912 & $\$ 69,985$ & $\$ 18.0$ & $\$ 300.44$ \\
\hline Rockville, MD & $\$ 0.271$ & 63,170 & $\$ 53,754$ & $\$ 10.1$ & $\$ 160.46$ \\
\hline Charlotte, NC & $\$ 7.616$ & 695,995 & $\$ 24,858$ & $\$ 229.7$ & $\$ 330.03$ \\
\hline Fayetteville, NC & $\$ 1.058$ & 181,453 & $\$ 34,245$ & $\$ 28.0$ & $\$ 149.33$ \\
\hline Winston-Salem, NC & $\$ 1.413$ & 224,889 & $\$ 35,666$ & $\$ 79.0$ & $\$ 351.28$ \\
\hline
\end{tabular}

Analysis of the cities' responses to GASB 45 and its informational content was based on examination of their respective comprehensive annual financial reports (FY 2006 through FY 2010) and other government documents. Data from FY 2006 through FY 2008 were used to determine how the cities responded to the implementation of GASB 45. Follow-up information using data for FY 2009 and FY 2010 was used to update the cities' responses. City finance and budget directors were also surveyed to obtain information about compliance with GASB 45 and its impact on OPEB provision.

\section{Richmond, Virginia}

Of all the cities studied, Richmond, Virginia, had adopted the most proactive strategy to reduce its unfunded liability. The city's original UAAL was $\$ 194$ million, which prompted the city to make significant changes to its retiree healthcare program. This reduced the liability by almost $\$ 120$ million to $\$ 76$ million. The most 
significant change was to eliminate the Medicare subsidy provided to its retirees. This was accomplished by enrolling retirees in the Medicare Advantage program instead of keeping them on the OPEB plan. Second, all employees hired after January 1, 1997, were moved into a DC retiree healthcare plan (in the form of a HSA), and those employees receive no retiree healthcare in the future. Finally, for current retirees and employees hired prior to January 1, 1997, the city froze its retiree healthcare contributions at the 2007 levels. By aggressively redesigning the OPEB, Richmond was able to significantly reduce and limit its OPEB liability. The city decided not to set up a trust fund to prefund the remaining benefits promised to their pre-1997 employees, but did set aside (in 2008) $\$ 650,000$ towards future OPEB costs. In 2009 and 2010 the city set aside $\$ 1.4$ million per year towards its OPEB liability. This amount was significantly less than the ARC and is roughly equal to the normal cost component of the ARC.

\section{Alexandria, Virginia}

The City of Alexandria, Virginia, decided to continue to provide retiree healthcare and to prefund the liability. This was accomplished by creating an OPEB trust fund and making an initial deposit of $\$ 5.6$ million in 2008 as well as identifying an additional $\$ 10.7$ million from the ending General Fund balance from FY 2008 for deposit into the trust fund. The city made several changes to its employee healthcare plan, which affected retirees, as they participate in the employee healthcare plan. The city's monthly contribution is a fixed $\$ 260$ per person toward the healthcare premium and the remaining balance is the responsibility of the retiree. Healthcare premiums were increased by 3.3 percent in FY 2007, and this increase was borne solely by retirees. In addition, retiree healthcare for employees hired after September 30, 2007, will be prorated based on the length of service. While not related to retiree healthcare, the city also decided that employees hired after July 1, 2008 would not receive the retiree life insurance benefit that had been previously provided. This had the effect of lowering the overall OPEB liability for the city. The city's most recent actuarial valuation was on December 31, 2009 and at that time the OPEB trust fund was valued at $\$ 8.2$ million and the AAL was $\$ 90.7$ million (resulting in an UAAL of $\$ 82.5$ million which is a funding ratio of $9 \%$ ). This was after the city made the full ARC payment for both 2009 and 2010. 


\section{Virginia Beach, Virginia}

The City of Virginia Beach decided that it would continue to provide retiree healthcare and that it would prefund the OPEB and establish a trust fund. In 2007 the city created an Employee Benefits Review Task Force, whose members represented City Council, city employees, public safety employees, and citizens and business owners. The Task Force developed an overall strategy of reducing the unfunded retiree healthcare liability and, to the extent practical, funding the ARC. Recommendations made by the task force became effective in FY 2009. The city's first ARC was made on June 30, 2008 , in the amount of $\$ 10.3$ million. The city has contributed 100 percent of the ARC into the trust fund for all fiscal years since implementation of GASB 45.

Reducing the OPEB liability involved significant changes to the OPEB promises. First, length of service necessary for retiree health insurance eligibility was increased from 5 years to 25 years. Second, the city shifted more costs to employees, in the form of reduced employer subsidies and increased employee co-pays, deductibles, and out-of-pocket maximums. The city eliminated the zero premium (i.e., $100 \%$ employer subsidy) healthcare option for single subscriber retirees, in addition to introducing a graduated subsidy plan capped at 50 percent. In FY 2010 the city offered employees the option to switch from the current DB plan to a DC plan with a HSA. However, limited enrollment in the HSA option indicates that it is unlikely to substantially reduce the unfunded liability.

\section{Baltimore, Maryland}

Baltimore has, by far, the largest liability of the cities included in this study. Maryland is a right-to-strike state, and Baltimore has union contracts that made it impossible for the city to consider changing or eliminating its OPEB to reduce the liability. Given the size of the UAAL ( $\$ 2$ billion for the city and its school system combined), carrying an unfunded liability of that magnitude on the financial disclosure and reporting documents could have a negative effect on the city's bond ratings. Therefore prefunding was the only option, and in FY 2008 the city established an OPEB trust fund and contributed $\$ 183.3$ million. This represented $\$ 18.7$ million more than the ARC and was an increase of $\$ 78.6$ million over the previous year's PAYGO amount. For FY 2009 the city contributed $\$ 142.3$ million to the OPEB 
trust fund ( $\$ 37$ million less than the ARC). For FY 2010 the city again contributed $\$ 142.3$ million to the OPEB trust fund (the ARC was $\$ 203.7$ million). Despite the prefunding strategy, as of June 30 , 2010 , the UAAL for the city of Baltimore was $\$ 2.6$ billion, an increase of $\$ 415$ million since June 30, 2008.

\section{Gaithersburg, Maryland}

Gaithersburg, Maryland, adopted a proactive strategy, implementing GASB 45 a year earlier than required. The city decided to prefund its existing OPEB with no plan changes. The city pays 85 percent of the retiree's health and dental premiums as well as 100 percent of the life insurance premiums. An employee must have at least 15 years of service to qualify for the OPEB. In FY 2007, the city established an OPEB trust fund with an initial deposit of $\$ 2.6$ million (over two and a half times the ARC). However in subsequent years (FY 2008 through FY 2010) the city's contribution to the trust fund was significantly below the ARC: 32 percent, 47 percent, and 10percent of the ARC, respectively. According to the most recent actuarial valuation of the OPEB plan (completed July 1, 2009), the AAL was $\$ 24.9$ million and the UAAL was $\$ 22.9$ million.

\section{Rockville, Maryland}

The City of Rockville, Maryland, faced a very small OPEB liability, primarily because in order to qualify for the benefit, retirees must be at least 60 years old with ten years of service. This has had the effect of minimizing the "window" within which the retiree will receive OPEB before being eligible for Medicare at age 65 . Because the benefits were already minimal, the city decided to make no plan changes. In 2009 the city established a trust fund and made the full ARC payment of $\$ 1.3$ million. However, in the following year the city funded only $\$ 237,000$ of the $\$ 1.4$ million ARC.

\section{Charlotte, North Carolina}

Prior to GASB 45, the City of Charlotte, North Carolina, offered a modest OPEB in which retirees with at least 15 years of service were eligible for the healthcare plan and the city subsidized 85 percent of the premium. Employees who retired with at least ten but less than 15 years of service were allowed to participate in the plan but had to pay the full premium. Those with less than ten years of service 
received no benefits. With the implementation of GASB 45 , no changes to those eligibility and participation requirements were made. Instead, the city adopted an aggressive prefunding strategy and focused on building the asset base needed to pay for future benefits.

In FY 2008, the city established a trust fund and made a payment of $\$ 28.4$ million (166\% of the ARC). For 2009 and 2010 the city contributed 195 percent and 104 percent of the ARC payment, respectively. The most recent actuarial valuation (as of July 1, 2009) was $\$ 174$ million, which suggests that the aggressive prefunding strategy has been able to reduce the OPEB unfunded liability.

\section{Fayetteville, North Carolina}

The City of Fayetteville, North Carolina, decided to continue to offer healthcare coverage to its retirees, but has made changes to the healthcare plan in an effort to reduce OPEB liabilities. For employees hired after February 1,2008, eligibility to participate in the retiree healthcare plan is based on 20 years of credible service. This is a considerable increase from the previous requirement of only 5 years of service. In addition, retirees will only be able to carry a dependent on the plan if that dependent was on the plan for the consecutive five years prior to retirement, and the dependent must pay the full premium.

However, the city has not yet decided whether to prefund the liability, and as of June 2010, the city was still using PAYGO. Despite continuing with the PAYGO approach and not prefunding, the city has seen a reduction in its UAAL, from $\$ 28$ million in 2008 to $\$ 15$ million in 2009 , which could be largely due to changes to the plan.

\section{Winston-Salem, North Carolina}

The City of Winston-Salem, North Carolina, also decided to continue to provide retiree healthcare, while adopting an aggressive prefunding strategy. In January 2008 the city established an OPEB trust fund with $\$ 34.8$ million (44.1\% of the UAAL). In subsequent years (FY 2009 and 2010) the city contributed 100 percent of the ARC amount.

The city also made plan changes to reduce its liability. For example, the city increased the required number of credible service 
years to 15. Dependents will be allowed on the plan only if they pay the full group rate premium. For those retirees who qualify for the OPEB, the city limited its annual contribution to $\$ 2,400$ per retiree, with increases in premiums, co-pays, and deductibles beyond this amount to be covered by the retiree. As of the most recent actuarial valuation on January 1,2010 , the OPEB liability was almost halffunded (48.5\%), as the AAL was $\$ 80.6$ million, and plans assets were valued at $\$ 39.1$ million.

\section{CONCLUSION AND IMPLICATIONS}

The examples discussed in this paper show that local governments have responded to GASB 45 using a combination of strategies. The findings of the NCSC study of counties and the case studies of nine mid-Atlantic cities indicate that local governments have responded to GASB 45 and the knowledge of the magnitude of their OPEB liabilities in four different ways (see Figure 2). Improving the asset base appears to be a popular response to reducing the unfunded liability with almost 70 percent of the cities and counties included in this study taking steps to prefund their OPEB. However, some local governments $(43.5 \%)$ have also responded by reducing or eliminating retiree healthcare.

As illustrated in this paper, coming to grips with the OPEB unfunded liabilities has resulted in some local governments not only reconsidering their OPEB plan designs, but also contemplating eliminating their OPEB. While the severity of plan redesign and possible discontinuation of OPEB plan offerings by government employers will typically depend on the magnitude of the unfunded liability, the current fiscal environment facing governments is such that even those cities with smaller OPEB liabilities may consider reducing or eliminating their OPEB as a way to reduce future liabilities and outgoing cash flows.

Several authors and studies have suggested measures for governments to manage their OPEB liabilities. For example, Russell (2008) suggested several approaches to controlling OPEB liabilities, including the following:

- Modifying the cost-sharing philosophy by requiring retirees to pay an increased share. 
FIGURE 2

OPEB Liabilities in Four Different Ways

OPEB Promises

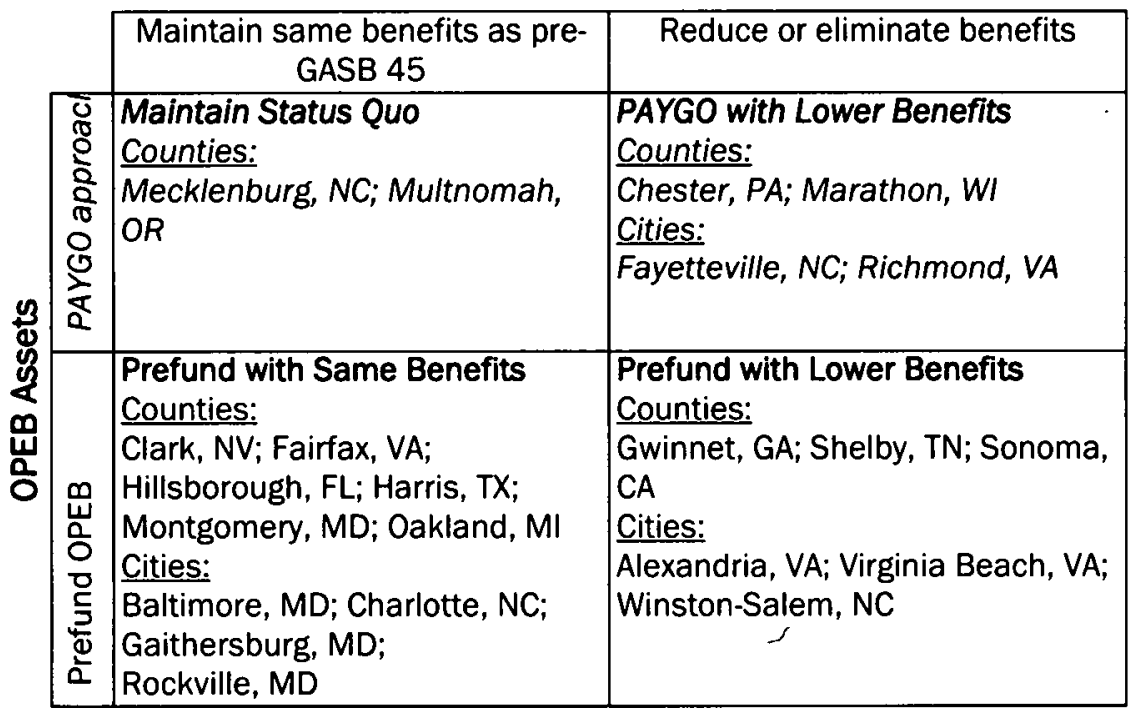

Note: Tulsa, OK was included in the NCSC study of county responses but is not included in this summary figure because the county does not offer a DB OPEB plan. Bernalillo, NM was also not included because its retirees participate in the state retiree health plan and the county has no liability.

- Increasing eligibility requirements for receiving benefits or reducing benefits if retirement occurs after a certain date.

- Limiting employer liability exposure by reducing duration of coverage, capping employer annual claims costs per retiree, and capping employer aggregate costs, or introducing DC plans.

- Modifying benefit designs such as changes to deductible, copayments, co-insurance, and out-of-pocket limits.

- Other cost management strategies such as switching retirees to Medicare advantage and Medicare supplement plans.

Examples of how these approaches have been implemented by counties and cities in this study are presented in Table 2. 


\section{TABLE 2}

Strategies and Approaches for Reducing Benefits

\begin{tabular}{|c|c|}
\hline Strategy/Approach & Example \\
\hline \multicolumn{2}{|c|}{ Modifying the Cost-Sharing Philosophy } \\
\hline $\begin{array}{l}\text { - Different subsidies for } \\
\text { retirees vs. dependents }\end{array}$ & Winston-Salem: Dependents pay full premium. \\
\hline $\begin{array}{l}\text { - Linking retiree } \\
\text { contributions to years of } \\
\text { service }\end{array}$ & $\begin{array}{l}\text { Charlotte: Employees with } 15 \text { years of service } \\
\text { are allowed to participate in the healthcare plan } \\
\text { and the city pays } 85 \text { percent of the premium. } \\
\text { Employees who retire with at least ten but less } \\
\text { than } 15 \text { years of service are allowed to } \\
\text { participate in the plan but must pay the full } \\
\text { premium. }\end{array}$ \\
\hline \multicolumn{2}{|c|}{$\begin{array}{l}\text { Increasing Eligibility Requirements for Receiving Benefits or Reducing } \\
\text { Benefits If Retirement Occurs after a Certain Date }\end{array}$} \\
\hline $\begin{array}{l}\text { - Increasing eligibility } \\
\text { requirements for } \\
\text { receiving benefits }\end{array}$ & $\begin{array}{l}\text { Fayettevile: } 20 \text { years of credible service } \\
\text { required for a retiree to participate in the } \\
\text { healthcare plan. }\end{array}$ \\
\hline $\begin{array}{l}\text { - Reducing benefits if } \\
\text { retirement occurs after a } \\
\text { certain date }\end{array}$ & $\begin{array}{l}\text { Chester County: Eliminate the healthcare } \\
\text { benefit for employees retiring after June } 30 \text {, } \\
2006\end{array}$ \\
\hline \multicolumn{2}{|c|}{ Limiting Employer Liability Exposure } \\
\hline $\begin{array}{l}\text { - Limiting employer annual } \\
\text { costs per retiree }\end{array}$ & $\begin{array}{l}\text { Winston-Salem: Limit the annual contribution to } \\
\$ 2,400 \text { per retiree, with increases in premiums, } \\
\text { co-pays and deductibles beyond this amount to } \\
\text { be covered by the retiree. }\end{array}$ \\
\hline $\begin{array}{l}\text { - Capping employer } \\
\text { aggregate costs }\end{array}$ & $\begin{array}{l}\text { Richmond: For current retirees and employees } \\
\text { hired prior to January } 1,1997, \text { the city froze its } \\
\text { contributions to retiree healthcare at the } 2007 \\
\text { levels. }\end{array}$ \\
\hline -Introducing DC plans & $\begin{array}{l}\text { Virginia Beach: Provide employees the option of } \\
\text { switching from the current DB plan to a HSA (DC } \\
\text { plan). }\end{array}$ \\
\hline $\begin{array}{l}\text {-Changing deductibles, co- } \\
\text { payments, co-insurance, } \\
\text { and/or out-of-pocket } \\
\text { limits }\end{array}$ & $\begin{array}{l}\text { Virginia Beach: Increase retiree co-pays, } \\
\text { deductibles and out-of-pocket maximums. }\end{array}$ \\
\hline $\begin{array}{l}\text { - Switching retirees to } \\
\text { Medicare supplement } \\
\text { plans }\end{array}$ & $\begin{array}{l}\text { Richmond: Enroll retirees in Medicare } \\
\text { Advantage program. }\end{array}$ \\
\hline
\end{tabular}


This study utilized a sample of 15 counties (from across the country) and nine Mid-Atlantic cities as the basis of the analysis of local government responses to GASB 45 and its informational contents regarding OPEB liabilities. The counties and cities varied in terms of size, measured as population, government net assets, and government workforce and retirees. Furthermore, the cities and counties represent both urban and rural areas, and right-to-work and right-to-strike states. While the cities are all from the mid-Atlantic region, there is no reason to believe that their responses to GASB 45 are driven by regional factors, particularly since many of their responses are similar to those of the counties. This suggests that the findings are, with some degree of confidence, generalizable to local governments throughout the country.

\section{Implications}

The goal of this paper was to highlight the variety of ways that local governments have responded to knowledge about their OPEB liabilities, and to show that some of these measures have resulted in reduced benefits for government employees. The next paragraphs discuss the implications of these responses to GASB 45.

Clearly, the accounting and reporting standards of GASB 45 have serious implications for government employers. Clark (2008) argued that GASB 45 serves as "an important tool for policymakers and stakeholders in determining future compensation and employment policies and tax policies" (p. 3). In complying with GASB 45 , governments are able to generate information about OPEB that is useful to policymakers, investors, and other stakeholders. While in the beginning GASB 45 may introduce staggering liabilities to government employers' balance sheets, "in the longer term, it might bring into sharper focus for both the electorate and elected officials the fact that massive financial commitments have been made to public employees that will be progressively more difficult to meet" (Hurley et al., 2006, p. w203). Furthermore, information resulting from compliance with GASB 45 may shed light on instances where current and future funding of OPEB would strain a government's operations or where conditions are such that governments are unable to fulfill their OPEB obligations (Bell, 2006).

In the recent ICMA Survey of Local Government Employee Health Insurance Programs (ICMA, 2007), cities and counties were asked 
the amount of their OPEB liabilities. Interestingly, 26 percent of respondents were not sure of their estimated OPEB liabilities. Clearly, the reporting requirements of GASB 45 are needed to ensure that those cities and counties are aware of the future funding needed to ensure that they can keep the promises made to their employees and retirees. As McKethan et al. (2006) suggested, "GASB 45 is an important and needed contribution to public accounting and oversight that will help ensure that public officials will take the future costs of such programs into account when setting retiree benefits and premiums" (p. 1523). It can be argued that the costs associated with reduced benefits are a reasonable tradeoff for the increased confidence of knowing that the needed assets have been put aside to deliver on those promises. For government employees, despite possibly experiencing reductions in OPEB, there is greater security in knowing that the retiree benefits retained will be more fully accounted for and better funded.

It is also important to note that GASB 45 may not entirely be at fault for the reduction in retiree healthcare benefits. Beyond disclosing the liabilities and costs of governments' OPEB, GASB 45 does not require governments to take any actions to manage their OPEB liabilities. Therefore, the resulting changes in benefits should not be blamed entirely on GASB 45. In many instances, the effect on OPEB of GASB 45 cannot be differentiated from other economic and fiscal factors:

Clark (2008) argued that most government OPEB plans are regularly amended, as government employers periodically increase premiums, raise deductibles, increase co-payments, restrict choices, or raise eligibility criteria. Wiesnewski $(2005$, p. 118$)$ suggested that implementation of GASB 45 is "less likely to influence the employer's decision to continue to provide such benefits than other strong economic factors such as significant continued healthcare cost inflation and a continued deterioration in the active-to-retiree workforce ratio in state government employment." In the face of the current fiscal crisis, it would not be surprising if more and more state and local governments turn to benefit plan redesign as a means of reducing their overall OPEB liabilities, not because of GASB 45 but because of economic pressures. Therefore, when coupled with factors such as the growth in medical and healthcare costs and the decreasing ratio of active employees to retirees in the public sector, 
GASB 45 may result in local governments reducing their OPEB in order to avoid additional liabilities.

Finally, GASB 45 may also have implications for how governments think about their other unfunded liabilities. The Cobalt Community Research survey (2009) asked respondents whether their GASB 45 and OPEB experiences had heightened their awareness of other longterm liabilities. A majority (59\%) of respondents answered in the affirmative; 27 percent indicated that GASB 45 has increased their awareness of other similar liabilities and had prompted them to begin planning for these liabilities. The other 32 percent, while being more aware, were insufficiently concerned about the liabilities to begin planning for them.

Even while government employers deal with issues arising from the information provided through the implementation of GASB 45, several other concerns must also be addressed. Surrounding the overarching questions of whether to prefund (and the potential fiscal impact of higher contributions associated with prefunding) and whether the existing benefit structure will be maintained are key issues such as (1) the extent to which any decreases in benefits undercut government's competitive ability to hire needed employees; (2) the affordability of prefunding; (3) the political hazards associated with addressing OPEB liabilities; (4) legal issues associated with OPEB levels and the possible reductions in such levels; and (5) the effect on bond ratings of decisions to address OPEB liabilities (Young, 2005). These questions were not addressed in this study. However, as more local and state governments are forced to come to grips with their OPEB plans and the associated liabilities, these issues will come increasingly to the forefront of policy discussion. These issues provide ample opportunity for continued future research on the financial, human resources, and political implications of GASB 45 and the recent realization by government employers of their OPEB liabilities.

\section{NOTES}

1. It may have been the absence of both the equivalent standards (to GASB 45) and the greater disclosure and transparency resulting from such standards that precipitated the underlying financial problems. However, the additional financial pressures 
associated with making the ARC payments could contribute to substantial additional stress.

2. While it is possible that another option would be to increase OPEB benefit levels, existing concern over sustainability of OPEB promises suggest that it is unlikely that government employers will raise benefits.

\section{REFERENCES}

Bell, L.L. (2006, March-April). "GASB 34 and GASB 45 OPEBs New Problems, Old Solutions?" Journal of Retirement Planning, 9 (2): 29-37.

Binnis, H. \& Riffe, S. (2000). "Cost/Benefit Tradeoffs Relating to Reductions in Postretirement Health Care Benefits in the SFAS Environment." Journal of Applied Business Research, 16 (4): 95104.

Clark, R.L. (2008). Financing Retiree Health Care: Assessing GASB 45 Estimates and Liabilities. Washington, DC: Center for State and Local Government Excellence.

Cobalt Community Research (2009). Health and OPEB Funding Strategies: 2009 National Survey of Local Governments. Lansing, MI: Cobalt Community Research.

Coe, C.K. \& Rivenbark, W.C. (2010). “Implementing GASB 45: Recommended Best Practices in Local Government." Public Budgeting and Finance, 30(4): 71-81.

Coggburn, J.D. \& Kearney, R.C. (2010). “Trouble Keeping Promises? An Analysis of Underfunding in State Retiree Benefits." Public Administration Review, 70 (1): 97-108.

Feldman, M. \& Haynes, R. (2007). "Effect of New GASB 45 Accounting Rules: What We Can Learn from FAS 106." Benefits \& Compensation Digest, 44 (3): 18-21.

Governmental Accounting Standards Board. (2004). Accounting and Financial Reporting by Employers for Post-Employment Benefits Other than Pensions: Statement No. 45. Norwalk, CT: GASB.

Governmental Accounting Standard Board (n.d). Other Postemployment Benefits: A Plain-Language Summary of GASB 
Statements No. 43 and No. 45. [Online]. Available at http://www.gasb.org/cs/ContentServer?c=Document_C\&pagena me=GASB\%2FDocument_C\%2FGASBDocumentPage\&cid $=11758$ 04850577. [Retrieved October 10, 2010].

Hurley, R.E., Felland, L., Gerland, A. \& Pickreign, J. (2006). "Public Employees' Health Benefits Survive Major Threats, So Far." Health Affairs, 25 (3): w195-w203.

International City/County Management Association (2007). Local Government Employee Health Insurance Programs, 2006. Washington, DC: International City/County Management Association.

Keating, E.K. \& Berman, E.S. (2007). "Unfunded Public Employee Health Care Benefits and GASB No. 45." Accounting Horizons, 21 (3): 245-263.

Kilgour, J.G. (2009). "Public Sector Retiree Benefits in California: Problems and Solutions." Compensation Benefits Review, 41: 27 32.

Marlowe, J. (2008). "Financial Management Challenges of Other Postemployment Benefits." In C.G. Reddick \& J.D. Coggburn (Eds.), Handbook of Employee Benefits and Administration (pp. 211-234). Boca Raton, FL: CRC Press.

McKethan, A., Gitterman, D., Feezor, A. \& Enthoven, A. (2006). “New Directions for Public Health Care Purchasers: Responses to Looming Challenges." Health Affairs, 25 (6): 1518-1528.

McTague, J. (2006, March 13). “The Trillion Dollar Pothole." Barron's Magazine: 37.

Mead, D.M. (2008). "Accounting and Financial Reporting by Governments for Retirement Benefits: Understanding and Using the Information in Audited Financial Reports." In C.G. Reddick \& J.D. Coggburn (Eds.), Handbook of Employee Benefits and Administration (pp. 285-307). Boca Raton, FL: CRC Press.

Mittelstaedt, H., Nichols, W. \& Regier, P. (1995). "SFAS 106 and Benefit Reductions in Employer-Sponsored Retiree Health Plans." Accounting Review, 70(4): 535-556. 
Moran, J.A. (2010). "The OPEB Tsunami: Riding the Wave of Public Sector Postemployment Health Benefits." Buffalo Law Review, 58 (3): 677-713.

Patterson, M.P. (2001). "State and Local Governments Plan Alternatives for Retiree Medical Benefits Funding." Compensation and Benefits Review, 33 (2): 37-49

Pearson, T.A. \& Jerris, S.I. (1995). “Accounting for OPEBs: Does Better Accounting Serve the Public Interests?" Journal of Applied Business Research, 11 (3): 1-7.

Russell, R.E. (2008, December). “GASB 45: Governmental Employers are Seeking Balanced Solutions." Benefits and Compensation Digest: 34-38.

Sanford, P. (2007). The Implementation of GASB 45 Case Studies of 15 Counties. Report prepared for the National Center for the Study of Counties. Washington, DC: National Association of Counties.

Voorhees, W.R. (2005). "Counting Retirement Expenditures Before they Hatch: GASB and the New Reporting Requirements for Other Postemployment Benefits." Public Budgeting and Finance, 25 (4): 59-71.

Wisniewski, S.C. (2005). “Potential State Government Practices Impact of the New GASB Accounting Standard for Retiree Health Benefits." Public Budgeting and Finance, 25 (1): 104-118

Young, P. (2005). "Funding OPEB Liabilities: What Are Your Options?" Government Finance Review, 21 (6): 10-15.

Zion, D. \& Varshney, A. (2007). You Dropped a Bomb on Me, GASB: Uncovering $\$ 1.5$ Trillion in Hidden OPEB Liabilities for State and Local Governments. New York: Credit Suisse Equity Research. 


\section{APPENDIX 1}

Summary Information for Counties in the NCSC Study(a)

\begin{tabular}{|c|c|c|c|c|}
\hline County & $\begin{array}{c}\text { AAL } \\
\text { (\$million) }\end{array}$ & $\begin{array}{c}\text { ARC } \\
\text { (\$million) }\end{array}$ & $\begin{array}{c}\text { Government } \\
\text { Employment } \\
\text { FTE }\end{array}$ & $\begin{array}{l}\text { Response to GASB } 45 \text { and } \\
\text { Information About OPEB } \\
\text { Liabilities }\end{array}$ \\
\hline $\begin{array}{l}\text { Bernalillo, } \\
\text { NM }\end{array}$ & $\mathrm{n} / \mathrm{a}$ & $\mathrm{n} / \mathrm{a}$ & 1,608 & $\begin{array}{l}\text { County participates in the } \\
\text { state retiree healthcare } \\
\text { program and has no liability }\end{array}$ \\
\hline Tulsa, OK & 1 & $n / a$ & $n / a$ & $\begin{array}{l}\text { County already offered HSA, } \\
\text { so only have minimal liability } \\
\text { due to implicit rate subsidies } \\
\text { - Retirees have access to } \\
\text { county health plan but pay } \\
100 \% \text { of premiums }\end{array}$ \\
\hline Chester, PA & 4 & 1 & 2,290 & $\begin{array}{l}\text { Eliminated healthcare } \\
\text { benefits for employees } \\
\text { retiring after June } 30,2006\end{array}$ \\
\hline $\begin{array}{l}\text { Marathon, } \\
\text { WI }\end{array}$ & 5 & 0.1 & 838 & $\begin{array}{l}\text { County already offered HSA, } \\
\text { so only have minimal liability } \\
\text { due to implicit rate subsidies }\end{array}$ \\
\hline $\begin{array}{l}\text { Hillsbo- } \\
\text { rough, FL }\end{array}$ & 100 & 8.2 & 10,429 & $\begin{array}{l}\text { Cost-allocate the ARC across } \\
\text { the department as part of the } \\
\text { cost of each FTE }\end{array}$ \\
\hline $\begin{array}{l}\text { Multnomah, } \\
\text { OR }\end{array}$ & 110 & 12.7 & 4,281 & $\begin{array}{l}\text { PAYGO for } 2008 \\
\text { - No plan changes }\end{array}$ \\
\hline $\begin{array}{l}\text { Gwinnett, } \\
\text { GA }\end{array}$ & 140 & 13.6 & 4,586 & $\begin{array}{l}\text { - Switched from a DB plan to a } \\
\text { DC plan } \\
\text { - Created a locally controlled } \\
\text { OPEB trust and pension plan }\end{array}$ \\
\hline $\begin{array}{l}\text { Mecklen- } \\
\text { burg, NC }\end{array}$ & 141 & 14.6 & 4,282 & $\begin{array}{l}\text { No changes to benefits as the } \\
\text { county recognizes that OPEBs } \\
\text { are important } \\
\text { recruitment/retention tools }\end{array}$ \\
\hline Fairfax, VA & 143 & 15.2 & 10,999 & $\begin{array}{l}\text { Focus on funding the ARC } \\
\text { - Created OPEB trust fund } \\
\text { No changes to health plans }\end{array}$ \\
\hline Shelby, TN & 267 & 28.2 & 6,277 & $\begin{array}{l}\text { Significantly reduced retiree } \\
\text { benefits package for new } \\
\text { employees } \\
\text { - No changes for current } \\
\text { employees }\end{array}$ \\
\hline Clark, NV & 372 & 49.7 & 18,705 & $\begin{array}{l}\text { - Partially funding ARC } \\
\text { - No changes to health plan }\end{array}$ \\
\hline
\end{tabular}


APPENDIX 1 (Continued)

\begin{tabular}{|l|c|c|c|l|}
\hline County & $\begin{array}{c}\text { AAL } \\
\text { (\$million) }\end{array}$ & $\begin{array}{c}\text { ARC } \\
\text { (\$million) }\end{array}$ & $\begin{array}{l}\text { Government } \\
\text { Employment } \\
\text { FTE }\end{array}$ & $\begin{array}{l}\text { Response to GASB 45 and } \\
\text { Information About OPEB } \\
\text { Liabilities }\end{array}$ \\
\hline Sonoma, CA & 382 & 37.2 & 4,154 & $\begin{array}{l}\text { Reduced employer contribu- } \\
\text { tion to the healthcare } \\
\text { premium }\end{array}$ \\
\hline Oakland, MI & 830 & 60.2 & 4,536 & $\begin{array}{l}\text { Has been prefunding OPEB } \\
\text { since 1980s and full AAL is } \\
\text { advance funded } \\
\text { Introduced HSA }\end{array}$ \\
\hline & & & & $\begin{array}{l}\text { Significantly reduced retiree } \\
\text { benefits package for new } \\
\text { employees } \\
\text { No changes for current } \\
\text { employees }\end{array}$ \\
\hline Harris, TX & 834 & 90.0 & 15,840 & $\begin{array}{l}\text { Full funding of ARC } \\
\text { implemented over a five year } \\
\text { period }\end{array}$ \\
\hline MD & & 240.0 & 9,089 & \\
\hline
\end{tabular}

Notes: Information about the number of government retirees is not available. Source: Research by the National Center for the Study of Counties (Sanford 2007).

\section{APPENDIX 2}

Summary Information for Selected Cities (2008)

\begin{tabular}{|c|c|c|c|c|c|}
\hline City & $\begin{array}{l}\text { AAL } \\
\text { (\$million) }\end{array}$ & $\begin{array}{l}\text { ARC } \\
\text { (\$million) }\end{array}$ & \begin{tabular}{|l} 
Govt \\
Retirees
\end{tabular} & $\begin{array}{l}\text { Govt } \\
\text { Employees } \\
\text { (FTE) }\end{array}$ & $\begin{array}{l}\text { Response to GASB 45 } \\
\text { and Information about } \\
\text { OPEB Liabilities }\end{array}$ \\
\hline $\begin{array}{l}\text { Richmond, } \\
\text { VA(a) }\end{array}$ & 76.1 & 4.6 & 1,172 & 8,940 & $\begin{array}{l}\text { - Phasing out OPEB } \\
\text { through significant plan } \\
\text { changes }\end{array}$ \\
\hline $\begin{array}{l}\text { Alexandria, } \\
\text { VA(a) }\end{array}$ & 88.1 & 17.9 & 1,015 & 4,472 & $\begin{array}{l}\text { - Established OPEB Trust } \\
\text { Fund with initial deposit } \\
\text { of } \$ 5.5 \text { million } \\
\text { - Increased employee } \\
\text { premiums }\end{array}$ \\
\hline $\begin{array}{l}\text { Virginia } \\
\text { Beach, VA }\end{array}$ & 84.7 & 10.3 & 574 & 6,762 & $\begin{array}{l}\text { - Established OPEB Trust } \\
\text { Fund and made the ARC } \\
\text { payment } \\
\text { - Changed plan for } \\
\text { retirees and employees }\end{array}$ \\
\hline
\end{tabular}


APPENDIX 2 (Continued)

\begin{tabular}{|c|c|c|c|c|c|}
\hline City & $\mid \begin{array}{l}\text { AAL } \\
\text { (\$million) }\end{array}$ & $\mid \begin{array}{l}\text { ARC } \\
\text { (\$million) }\end{array}$ & \begin{tabular}{|l} 
Govt \\
Retirees
\end{tabular} & \begin{tabular}{|l} 
Govt \\
Employees \\
(FTE)
\end{tabular} & $\begin{array}{l}\text { Response to GASB } 45 \\
\text { and Information about } \\
\text { OPEB Liabilities }\end{array}$ \\
\hline $\begin{array}{l}\text { Baltimore, } \\
M D^{(a)}\end{array}$ & $\begin{array}{c}214,454 \\
.0\end{array}$ & 164.6 & 21,017 & 28,171 & $\begin{array}{l}\text { - Established OPEB Trust } \\
\text { Fund with ARC plus } \\
\$ 18.7 \text { million } \\
\text { - No changes to plans }\end{array}$ \\
\hline $\begin{array}{l}\text { Gaithers- } \\
\text { burg, MD }\end{array}$ & 9.7 & 0.9 & 27 & 363 & $\begin{array}{l}\text { - Established OPEB trust } \\
\text { fund with an initial } \\
\text { deposit of } 250 \% \text { of ARC } \\
\text { - No changes to plan }\end{array}$ \\
\hline $\begin{array}{l}\text { Rockville, } \\
\text { MD }\end{array}$ & $8.8^{(\mathrm{b})}$ & 1.3 & 18 & 535 & $\begin{array}{l}\text { - Established OPEB trust } \\
\text { fund with ARC payment } \\
\text { - No changes to plan }\end{array}$ \\
\hline $\begin{array}{l}\text { Charlotte, } \\
\text { NC }\end{array}$ & 229.7 & 17.0 & 1,895 & 6,577 & $\begin{array}{l}\text { - Established OPEB Trust } \\
\text { Fund with initial deposit } \\
\text { of } 166 \% \text { of the ARC } \\
\text { - No changes to health } \\
\text { plans }\end{array}$ \\
\hline $\begin{array}{l}\text { Fayette- } \\
\text { ville, NC }\end{array}$ & 28.0 & 6.6 & 436 & 1,996 & $\begin{array}{l}\text { - Set aside less than } \$ 1 \\
\text { million towards liability } \\
\text { - Made plan changes }\end{array}$ \\
\hline $\begin{array}{l}\text { Winston- } \\
\text { Salem, NC }\end{array}$ & 79.1 & $\$ 6.98$ & 1,056 & 2,660 & $\begin{array}{l}\text { - Established OPEB Trust } \\
\text { Fund with initial deposit } \\
\text { of } \$ 34.8 \text { million ( } 44 \% \text { of } \\
\text { UAAL) } \\
\text { - Made plan changes }\end{array}$ \\
\hline
\end{tabular}

Notes: (a) Figures are for city government and school district combined.

(b) As of January 1, 2009. 
Copyright of Journal of Public Budgeting, Accounting \& Financial Management is the property of PrAcademics Press and its content may not be copied or emailed to multiple sites or posted to a listserv without the copyright holder's express written permission. However, users may print, download, or email articles for individual use. 